GRASAS Y ACEITES 66 (2)

April-June 2015, e071

ISSN-L: 0017-3495

doi: http://dx.doi.org/10.3989/gya.0715142

\title{
Nutritional enrichment of vegetable oils with long-chain n-3 fatty acids through enzymatic interesterification with a new vegetable lipase
}

\author{
J.S. Sousa ${ }^{\mathrm{a}, \mathrm{b}, \bowtie}$, A.G. Torres ${ }^{\mathrm{b}}$ and D.M.G. Freire ${ }^{\mathrm{a}}$ \\ ${ }^{a}$ Universidade Federal do Rio de Janeiro, Instituto de Química, Laboratório de Biotecnologia Microbiana, Rio de Janeiro-RJ, Brazil \\ ${ }^{b}$ Universidade Federal do Rio de Janeiro, Instituto de Química, Laboratório de \\ Bioquímica Nutricional e de Alimentos, Rio de Janeiro-RJ, Brazil \\ Corresponding author: joab_sousa@oi.com.br
}

Submitted: 03 July 2014; Accepted: 01 December 2014

SUMMARY: The aim of the present work was to produce vegetable oils enriched with long-chain n-3 fatty acids of nutraceutical interest, through an enzyme-catalyzed interesterification with a new lipase, from physic nut (Jatropha curcas L.). The Vegetable Lipase Powder (biocatalyst) called VLP, which has never been applied in functional foods, was obtained from the physic nut seed, and efficiently hydrolyzed the $95 \%$ of waste fish oil in $24 \mathrm{~h}$. Urea precipitation was used to concentrate polyunsaturated fatty acids (PUFA) and was further interesterified with oils of different sources by means of enzymatic catalysis. After the interesterification reaction, which was also catalyzed by the VLP, the PUFA content in coconut oil increased almost ten-fold from $1.8 \%$ to $17.7 \%$. In palm oil, the PUFA content increased two-fold from $10.5 \%$ to $21.8 \%$, while in olive oil the level of PUFA increased from $8.6 \%$ to $21.3 \%$. The mixture of eicosapentaenoic acid (EPA) and docosahexaenoic acid (DHA) $(3.7 \%$ to $3.9 \%$ ) was incorporated into the triacylglycerol fraction of each of the coconut, palm and olive oils. Through the hydroesterification (hydrolysis followed by interesterification) all the interesterified vegetable oils tested presented sufficient EPA and DHA levels to satisfy the levels recommended for intake by human adults in one tablespoon.

KEYWORDS: Interesterification; Jatropha curcas L.; Lipase; Polyunsaturated fatty acids; Structured lipids

RESUMEN: Enriquecimiento nutricional de aceites vegetales con ácidos grasos $\boldsymbol{n}-\mathbf{3}$ de cadena larga mediante interesterificación enzimática con una nueva lipasa vegetal. El objetivo del presente trabajo fue producir aceites vegetales enriquecidos con ácidos grasos n-3 de cadena larga de interés nutraceutico, por interesterificación catalizada mediante una nueva lipasa, una enzima de semilla de Jatropha curcas L. La lipasa vegetal en polvo (biocatalizador) llamada VLP, nunca ha sido aplicada en alimentos funcionales, se obtuvo mediante procedimientos físicos con semillas de nueces, e hidrolizó eficientemente el 95\% de aceites de residuos de pescado en $24 \mathrm{~h}$. La precipitación con urea se utilizó para concentrar los ácidos grasos poliinsaturados (PUFA) que fueron posteriormente interesterificados con aceites de diferentes fuentes mediante catálisis enzimática. Tras la reacción de interesterificación, que también fue catalizada por la VLP, el contenido de PUFA en el aceite de coco aumentó casi diez veces de 1,8\% a 17,7\%. En el aceite de palma, el contenido de PUFA aumentó dos veces desde 10,5\% a 21,8\%, mientras que en el aceite de oliva el nivel de PUFA incrementó de 8,6\% a 21,3\%. La mezcla de ácido eicosapentaenoico (EPA) y ácido docosahexaenoico (DHA) $(3,7 \%$ a 3,9\%) fué incorporada a la fracción de triacilgliceroles de cada uno de los aceites, coco, palma y oliva. Mediante hidroesterificación (hidrólisis seguido de interesterificación) todos los aceites vegetales interesterificados ensayados contienen en una cucharada suficientes niveles de EPA y DHA para cubrir los niveles recomendados de ingesta de humanos adultos.

PALABRAS CLAVE: Ácidos grasos poliinsaturados; Interesterificación; Jatropha curcas L.; Lipasa; Lípidos estructurados

Citation/Cómo citar este artículo: Sousa JS, Torres AG, Freire DMG. 2015. Nutritional enrichment of vegetable oils with long-chain n-3 fatty acids through enzymatic interesterification with a new vegetable lipase. Grasas Aceites 66 (2): e071. doi: http://dx.doi.org/10.3989/gya.0715142.

Copyright: (C) 2015 CSIC. This is an open-access article distributed under the terms of the Creative Commons Attribution-Non Commercial (by-nc) Spain 3.0 Licence. 


\section{INTRODUCTION}

Lipases are very versatile biocatalysts thanks to the range of different reactions they are capable of catalyzing, offering several major advantages over classic catalysts, including their specificity, regioselectivity, and enantioselectivity (Freire and Castilho, 2008). The reactions catalyzed by these biocatalysts produce fewer byproducts, less wastewater, and use milder temperature and pressure conditions, minimizing the migration of acyl groups and oxidation processes (Hernández-Martín and Otero, 2008), thereby opening up a potentially huge range of biotechnology applications (Lee et al., 2006; Wu et al., 2006; Freire and Castilho, 2008).

Vegetable lipases are widely available in nature and are more readily accepted by the food and pharmaceutical industries than microbial lipases. They normally show particular selectivity, often for a substrate, and can be used profitably for the specific enrichment or isolation of a particular type or class of lipid (Yankah and Akoh 2000).

Vegetable lipases are a less studied alternative to the use of microbial lipases by the food industry. In this field, the synthesis of structured lipids (SL), which are for example triacylglycerols (TAGs) that have been restructured or modified to alter their fatty acid composition and/or their distribution in the glycerol molecule (Lee and Akoh, 1998; Sreenivasan, 1978) are very attractive products in the market. These modifications can alter their bioactivity and modify or improve their physical and/ or chemical characteristics, thus offering potential health benefits (Akoh, 1995), by changing the nutritional properties of food (Yankah and Akoh, 2000), for example, to reduce the caloric value of lipids (Gunstone, 1998; Auerbach et al., 2001).

With new findings concerning the positive effects that PUFA have on humans, there is increasing interest in different oils and fats for treating and preventing several diseases and improving health (Molendi-Coste; Legry; Leclercq, 2011; Connor, 2000; Stillwell, 2006). Structured lipids might be effective means of providing specific PUFA for nutritional and therapeutic purposes, like the treatment of specific diseases or abnormal metabolic conditions. They are also regarded as functional foods, which are foods or ingredients that have a positive impact on health above and beyond the basic nutrients they contain (Yankah and Akoh, 2000).

The global market offers a broad range of dietary supplements of PUFA (Mu et al., 1998), diet or lowcalorie products (Salatrim and Olestra) (Nagao et al., 2000; Kasai et al., 2003), drugs for hiperlipidemia (MaxEPA ${ }^{\circledR}$; Sevenseas Healthcare Ltd., UK) and cholesterol reduction (Omacor ${ }^{\mathbb{B}}$; Pronova Biocare, Norway), among others. These products are not used just to supplement the daily intake of specific PUFA, but also for clinical purposes (Mu et al., 1998).
Structured lipids may be synthesized by a transesterification reaction, either chemically or enzymatically. Chemical interesterification is promoted by heating mixtures of oils and free fatty acids (FFA) in the presence of a chemical catalysts, such as alkali metals or metal alkylates (Osborn and Akoh, 2002). During this process, all the fatty acids present in the mixture of lipids change position randomly in the TAG molecules (Akoh, 1995), making it difficult to control the nutritional or functional properties of the oils and fats obtained (Macrae and Hammond, 1985). However, when enzymes are used as catalysts for the interesterification, these problems might be overcome due to the regiospecificity of some lipases.

Coconut oil (Cocos nucifera L.) is a natural source of medium chain fatty acids (MCFA). 90\% of its composition is saturated fatty acids which makes it resistant to oxidative rancidity. The MCFA have numerous functional applications because they can stimulate the immune system, are used in weight control and as antimicrobial agents, such as dietary in cases of chronic degenerative disease, such as cardiovascular disease, liver disease and cancer (Gopala et al., 2010). Associated with this, the incorporation of PUFAs such as EPA and DHA proposed in this paper generates a structured lipid with a single MCFA and PUFA composition, which provides benefits to the sum of such effects in the immune system by increasing the intake of EPA and DHA in addition to the nutritional advantages of MCFA.

Palm oil (Elaeis guineensis) and its derivatives are commonly recognized in the food industry as having high oxidative stability due to its composition of fatty acids, carotenoids and tocotrienols; thus, it can be used at high temperatures and supports a long life of products (Foster et al., 2009; Embrandiri et al., 2013). It has low levels of polyunsaturated, particularly omega-3 fatty acids and its enrichment with these properties improves its nutritional fatty acids.

Olive oil (Olea europaea L.) has a privileged position among the edible oils because of its high consumption by the inhabitants of the Mediterranean basin (Oh et al., 2009). Over the past decades, nutritional and epidemiological studies have provided evidence that the consumption of virgin olive oil contributes to human health, due to the presence of antioxidant compounds and their derivatives (Frankel, 2011). However, in many cultures olive oil is more commonly used as a condiment (seasoning) to salads. The prerogative in this research would be to make it even more attractive from the point of view of nutrition by inserting PUFAs and consequently increasing the beneficial effects for the immune system by increasing the intake of EPA and DHA.

The aim of the present work was to produce vegetable oils enriched with long-chain n-3 fatty acids of 
nutraceutical interest, through an enzyme-catalyzed interesterification with a new lipase, from the physic nut (Jatropha curcas L.).

\section{MATERIALS AND METHODS}

\subsection{Source of lipase and oils}

The Vegetable Lipase Powder (biocatalyst) called VLP, used for the hydrolysis and interesterification reactions, was obtained from physic nut seeds (Jatropha curcas L.) as described by Cavalcanti et al. (2007) and characterized by Sousa et al. (2010).

This VLP showed activity $\left(96 \pm 4 \mathrm{U} \cdot \mathrm{g}^{-1}\right)$ using olive oil as substrate. One unit of lipase activity (U) was defined as the amount of enzyme necessary to produce $1 \mu \mathrm{mol}$ of FFA per minute, under assay conditions (Freire et al., 1997). This assay was done using $0.05 \mathrm{M}$ Tris- $\mathrm{HCl}$ buffer, $\mathrm{pH} 8.0$, at $40{ }^{\circ} \mathrm{C}$, as described by Sousa et al. (2010).

The refined coconut and palm oils had acidity of $0.4 \pm 0.1 \%$ and $6.2 \pm 0.2 \%$, respectively; the virgin olive oil had acidity of $1.2 \pm 0.2 \%$; and the fish oil (sardine waste) of $3.9 \pm 0.1 \%$. The vegetable oils were purchased from a local supermarket, and the fish oil was kindly supplied by the Guabi Nutrição Animal co. (Campinas-SP, Brazil). The solvents were of analytical or chromatographic grade, as appropriate.

In the present study we used a low cost substrate, which consisted of fish oil residue, and also a lowcost waste raw material and a crude biological catalyst (VLP), rendering the proposed method a greater applicability in industrial processes.

\subsection{Fatty acid composition of the raw materials and products}

The different lipids in the raw materials and products were separated by TLC and the bands related to the TAG were identified by comparing the relative elution of commercial standards. The samples were applied in a silica gel plate $\left(10 \mu \mathrm{L} \cdot \mathrm{cm}^{-1}\right)$ and lipid classes were separated with hexane:diethylether:acetic acid (70:30:1, v:v:v) as the mobile phase. The spots were revealed non-destructively with a $0.2 \%$ solution of 2,7-dichlorofluorescein in methanol, and then sprayed to make the spots visible under UV light.

The TAG spots corresponding to structured lipids were identified and scraped off the TLC onto a derivatization tube. The oils and FFAs were methylated according to the method described by Lepage and Roy (1986). The analysis of fatty acid methyl esters was performed on a gas chromatograph (CG2010; Shimadzu, Japão) equipped with a capillary column Omegawax $320(30 \mathrm{~m} \times 0.32 \mathrm{~mm} \times 0.25 \mu \mathrm{m}$; Sigma, São Paulo, Brazil). All tests were performed under the following conditions: injector temperature:
$260{ }^{\circ} \mathrm{C}$; carrier gas: helium at $4.0 \mathrm{~mL} \cdot \mathrm{min}^{-1}$; the sample injection volume was $1 \mu \mathrm{L}$ with split ratio: 1:20; column temperature gradient: $150{ }^{\circ} \mathrm{C}$ for 5 min, increased at $2{ }^{\circ} \mathrm{C} \cdot \mathrm{min}^{-1}$ to $210{ }^{\circ} \mathrm{C}$, and remained constant for $30 \mathrm{~min}$; flame ionization detector temperature: $280{ }^{\circ} \mathrm{C}$.

\subsection{Production and concentration of PUFA}

The reaction of hydrolysis of fish oil $50 \%(\mathrm{v} / \mathrm{v})$ in $0.1 \mathrm{M}$ Tris- $\mathrm{HCl}$ buffer $\mathrm{pH} 8.0$, without the addition of emulsifiers, was carried out with the VLP $(10 \%$ w/v; $100 \mathrm{U} / \mathrm{g}$ of substrate) at $40{ }^{\circ} \mathrm{C}$ for $48 \mathrm{~h}$.

The acidity, which indicates the percentage of FFA (w/w) in the oil, was titrated with a $0.04 \mathrm{~N}$ $\mathrm{NaOH}$ solution until $\mathrm{pH} 11.0$ using an automatic titrator. The samples $(0.1 \mathrm{~g})$ were solubilized in $40 \mathrm{~mL}$ of a solution composed of acetone and ethyl alcohol (1:1). The blanks were made by titrating the solution with no sample. The acidity was established according to equation (01):

$\operatorname{Acidity}(\% F F A)=\frac{N \cdot\left(V_{S}-V_{B}\right) \cdot M M}{10 \cdot m}$

Where:

$\mathrm{N}=\mathrm{NaOH}$ normality; $\mathrm{Vs}=$ volume of base used in sample titration $(\mathrm{mL}) ; \mathrm{Vb}=$ volume of base used in blank titration $(\mathrm{mL}) ; \mathrm{MM}=$ molecular mass of the predominant fatty acid $(\mathrm{g}) ; \mathrm{m}=$ sample mass $(\mathrm{g})$.

After the hydrolysis reaction, the FFA were extracted with hexane and PUFA were concentrated with urea precipitation, as described by GámezMeza et al. (2003) (Wanasundara and Shahidi, 1999).

\subsection{Enzymatic interesterification of vegetable oils with FFA enriched in n-3 PUFA}

The interesterification reaction was catalyzed by VLP with the following substrates: oils of coconut, palm and olive, and FFA enriched with n-3 PUFA, obtained from the urea-complexation of hydrolyzed fish oil (item 2.3). This reaction was catalyzed by VLP $10 \%(\mathrm{w} / \mathrm{v})$ in a $3: 1(\mathrm{~mol}: \mathrm{mol})$ ratio of FFA: oil, at $40{ }^{\circ} \mathrm{C}$ for $24 \mathrm{~h}$ in a thermostatized batch stirred reactor (BSR) under magnetic stirring. At the end of the reaction, the samples were diluted with $2.0 \mathrm{~mL}$ of $n$-hexane for extraction in a conical glass tube with PTFE-lined screw caps, and analyzed by thin layer chromatography (TLC). After the interesterification of the vegetable oils with FFA enriched with n-3 PUFA, lipid classes (TAG, DAG, MAG and FFA) the oils were separated by TLC (data not shown), but were not quantified. The TAG bands were scraped off and methylated for analysis according to the method described by Lepage and Roy (1986). 


\section{RESULTS AND DISCUSSION}

\subsection{Hydrolysis of fish oil and urea concentration of n-3 PUFA by complexing with urea}

The VLP was not purified once the initial idea was to prove that this vegetable lipase (not studied yet) would be capable of carrying out the interesterification reaction, which was the aim of the present work. In this case, it can be seen as a positive factor, once the biocatyst performance can be improved through purification (higher lipase activity) and immobilization technics (allowing lipase reuse by a larger number of cycles) like those already applied in commercial enzymes.

After $24 \mathrm{~h}$ of hydrolysis reaction the VLP had converted $95 \%$ of the fish oil into FFA, reaching $99 \%$ in $48 \mathrm{~h}$. This conversion efficiency was higher than that obtained by Hee-Guk et al. (2007), who studied the hydrolysis of sardine oil by six lipases, from porcine pancreas, Candida rugosa, Candida cylindracea, Rhizopus niveus, Mucor meihei and Pseudomonas sp. In this study, the reactions were conducted for 24 and $48 \mathrm{~h}$ in an ideal emulsion system, the highest yields of hydrolysis were obtained with the lipases from Pseudomonas sp. and porcine pancreas, with maximum yields of $80 \%$ FFA after $48 \mathrm{~h}$, which were lower than what we found for the VLP from the physic nut.

The fatty acid composition (Table 1) of fish oil was consistent with the date published data for fish oil fatty acids (Haraldsson and Hjaltason, 2001; Jennings and Akoh, 2001), with relatively high contents in the n-3 PUFA of nutritional interest, eicosapentaenoic (EPA) and docosahexaenoic acids (DHA). After hydrolysis for $24 \mathrm{~h}$, followed by urea complexation, the contents of EPA and DHA increased, respectively, approximately by $40 \%$ and $50 \%$ compared to the original fish oil.

Klinkerson et al. (2004) observed enrichments of approximately $80 \%$ and $200 \%$ in EPA and DHA contents, respectively, through the urea complexation of hydrolyzed refined tuna oil. Gámez-Meza et al. (2003) obtained 220\% enrichment with EPA and DHA in sardine oil hydrolysates with an immobilized lipase from Pseudomonas cepacia and 130\% and $210 \%$ with EPA and DHA, respectively, when the hydrolysis was conducted with a chemical catalyst. Possibly, these results of higher enrichment with n-3 PUFA, compared with the present work, can be explained by their use of refined, bleached and deodorized (RBD) fish oils.

TABLE 1. Fatty acid composition ( $\cdot 100 \mathrm{~g}^{-1}$ of total fatty acids) of oils: fish (FO), coconut (CO), palm (PO), olive (OO) and interesterified vegetable oils with the hydrolyzed and concentrated fish oil. The interesterification reaction was catalyzed by VLP $10 \%(\mathrm{w} / \mathrm{v})$ in a $3: 1(\mathrm{~mol}: \mathrm{mol})$ ratio of FFA:oil, at $40{ }^{\circ} \mathrm{C}$ for $24 \mathrm{~h}$

\begin{tabular}{|c|c|c|c|c|c|c|c|c|}
\hline \multirow[b]{2}{*}{ Fatty acid } & \multicolumn{8}{|c|}{ Samples of oils } \\
\hline & $\begin{array}{c}\text { Fish Oil } \\
\text { (FO) }\end{array}$ & FOHC & $\begin{array}{l}\text { Coconut } \\
\text { Oil }(\mathrm{CO})\end{array}$ & $\begin{array}{c}\text { Interesterified } \\
\mathrm{CO}+\mathrm{FOHC}\end{array}$ & $\begin{array}{l}\text { Palm Oil } \\
\text { (PO) }\end{array}$ & $\begin{array}{c}\text { Interesterified } \\
\text { PO+FOHC }\end{array}$ & $\begin{array}{c}\text { Olive Oil } \\
(\text { OO) }\end{array}$ & $\begin{array}{c}\text { Interesterified } \\
\text { OO+FOHC }\end{array}$ \\
\hline Caprilic acid - C8:0 & n.d. & n.d. & 6.20 & 3.61 & n.d. & n.d. & n.d. & n.d. \\
\hline Capric acid - C10:0 & n.d. & n.d. & 5.14 & 3.56 & 0.01 & 0.12 & n.d. & n.d. \\
\hline Lauric acid-C12:0 & 0.14 & n.d. & 46.85 & 31.94 & 0.16 & 0.15 & n.d. & n.d. \\
\hline Miristic acid - C14:0 & 4.24 & 2.12 & 19.40 & 14.85 & 0.65 & 1.42 & n.d. & 1.03 \\
\hline Palmitic acid-C16:0 & 15.64 & 3.96 & 9.86 & 7.49 & 36.04 & 27.89 & 11.11 & 9.58 \\
\hline Palmitoleic acid - C16:1 & 5.93 & 6.05 & n.d. & 3.45 & n.d. & 2.73 & 0.85 & 3.53 \\
\hline Stearic acid - C18:0 & 4.33 & 0.81 & 3.59 & 2.00 & 5.22 & 3.47 & 3.20 & 2.14 \\
\hline Oleic acid - C18:1n-9 & 25.38 & 26.48 & 7.19 & 14.58 & 46.97 & 41.37 & 75.74 & 61.50 \\
\hline Linoleic acid - C18:2n-6 & 15.72 & 20.02 & 1.77 & 11.26 & 10.55 & 15.51 & 8.04 & 14.53 \\
\hline Linolenic acid - C18:3n-3 & 2.21 & 2.77 & n.d. & 1.50 & n.d. & 1.24 & 0.63 & 1.58 \\
\hline Eicosenoic acid-C20:1n-9 & 2.33 & 2.50 & n.d. & 0.86 & 0.41 & 1.02 & 0.44 & 0.97 \\
\hline Eicosatetraenoic acid - C20:4n-3 & 1.07 & 1.61 & n.d. & 0.19 & n.d. & 0.18 & n.d. & 0.18 \\
\hline Araquidonic acid-C20:4n-6 & 0.69 & 1.01 & n.d. & 0.17 & n.d. & 0.20 & n.d. & 0.21 \\
\hline Eicosapentaenoic acid-C20:5n-3 & 8.99 & 12.89 & n.d. & 2.28 & n.d. & 2.27 & n.d. & 2.45 \\
\hline Docosapentaenoic acid-C22:5n-3 & 3.97 & 5.64 & n.d. & 0.82 & n.d. & 0.92 & n.d. & 0.91 \\
\hline Docosahexaenoic acid-C22:6n-3 & 9.35 & 14.14 & n.d. & 1.43 & n.d. & 1.51 & n.d. & 1.40 \\
\hline$\Sigma S F A$ & 24.2 & 6.9 & 91.0 & 63.4 & 42.0 & 33.1 & 14.3 & 12.7 \\
\hline$\Sigma M U S F A$ & 33.6 & 35.1 & 7.2 & 19.0 & 47.4 & 45.1 & 76.9 & 66.0 \\
\hline$\Sigma P U S F A$ & 42.0 & 58.0 & 1.8 & 17.7 & 10.5 & 21.8 & 8.6 & 21.3 \\
\hline Ratio n-6ln-3 & 0.67 & 0.59 & - & 1.85 & - & 2.57 & 13.33 & 2.23 \\
\hline
\end{tabular}

Values are means of duplicate analyses (deviation lower than $5 \%$ for all samples); n.d.: not detected, $\Sigma$ SFA: sum of saturated fatty acids, $\Sigma$ MUSFA: sum of monounsaturated fatty acids, $\Sigma$ PUSFA: sum of polyunsaturated fatty acids. 


\subsection{Fatty acid composition and nutritional properties of the interesterifed oils}

The fatty acid profiles of the vegetable oils, the waste fish oil and the interesterified oils after $24 \mathrm{~h}$ of reaction are presented in Table 1. Coconut oil has been incriminated as being atherogenic because of its lipid profile, which contains $90 \%$ saturated fatty acids, mostly composed of lauric acid. Coconut oil is rich in medium-chain fatty acids, but low in PUFA. However, after interesterification with the fish oil hydrolysate, the PUFA percentage increased from undetectable levels to final contents of 3.7\% EPA+DHA. However, this nutritional property of the interesterified oil is yet to be tested. Palm oil is the most important edible oil in the world's food market and one of the world's top commodities (Gunstone et al., 2007). As a consequence of its high saturated fatty acid and solid fat contents, palm oil is normally mixed with other liquid oils to improve its plasticity and melting properties, as it normally occurs in a semi-solid form (Fajardo et al., 2003). Palm oil is rich in natural antioxidants, especially tocotrienols, tocopherols and carotenoids (Goh et al., 1985). The initial fatty acid composition of palm oil consisted basically of palmitic and oleic acids, which accounted for approximately $80 \%$ of the total fatty acids (Table 1). After interesterification, the total PUFA contents increased two-fold, and the final contents of EPA+DHA were $3.8 \%$.

Olive oil is widely consumed in the Mediterranean basin and its regular consumption may bring health benefits, such as the prevention of cardiovascular diseases, and the modulation of immune and inflammatory states. It has been suggested that these positive effects of olive oil might be promoted by its antioxidant components, and high levels of oleic acid (Owen et al., 2000; Stark and Madar, 2002), which account for up to $75 \%$ of the total fatty acids in the oil. In the case of the interesterified olive-fish oil, a 2.5-fold increase in PUFA was observed, with a final content of EPA+DHA of $3.9 \%$.

The interesterified oils produced contain a more balanced mixture of all fatty acid classes: mediumchain, long-chain, saturated and polyunsaturated. This combination is capable of assuring both the provision of essential fatty acids and aiding in the absorption and digestion of medium-chain fatty acids, as described by Osborn and Akoh, (2002).

Klinkerson et al. (2004) studied the interesterification of RBD tuna oil and n-3 FAME, with the chemical catalyst sodium methoxide, at $80^{\circ} \mathrm{C}$ with an oil:n-3 FAME ratio of $1: 4$, and $5 \mathrm{~h}$ of reaction. The EPA content increased from 41 to $60.4 \mathrm{mg} \cdot \mathrm{g}^{-1}$ oil and the DHA content increased from 266 to $388 \mathrm{mg} \cdot \mathrm{g}^{-1}$ oil.

Fajardo et al. (2003) studied the interesterification of n-3 PUFA with RBD palm oil. The reaction was catalyzed by immobilized lipases from Rhizomucor miehei and Alcaligenes sp. After $24 \mathrm{~h}$ incubation in hexane, the average incorporation of EPA and DHA in the oil was $21 \%$ and $15 \%$, respectively. The authors observed that there was a $29 \%$ and $12 \%$ reduction in the palmitic and oleic acid content, respectively, and that more EPA and DHA was incorporated when EPAX (fish oil concentrate high in n-3 PUFA) was used in the form of an ethyl ester than when it was used in the form of a free fatty acid in the presence of a lipase from Rhizomucor miehei. In this case, the nutritional enrichment was lower than that obtained in the present work, despite the use of a raw material of superior quality and immobilized lipases. Rao et al. (2002) studied the incorporation of EPA and DHA from cod liver oil and linoleic acid (18:2n-6) from safflower oil in coconut oil, catalyzed by an immobilized lipase from Rhizomucor miehei. The contents of EPA and DHA increased from 0 to $14 \%$ (10\% EPA and 4\% DHA), with a 1:4 molar ratio for the coconut oil/n-3 PUFA, at $54{ }^{\circ} \mathrm{C}$ for $34 \mathrm{~h}$. Likewise, the maximum incorporation of linoleic acid was obtained at a 1:3 molar ratio of coconut oil/FFA at $39^{\circ} \mathrm{C}$ for $48 \mathrm{~h}$, obtaining $45.5 \%$ of linoleic acid.

In this case there was a greater incorporation of n-3 PUFA in coconut oil, however, it must be considered that an immobilized lipase, a higher molar ratio of PUFA coconut oil $/ \mathrm{n}-3$, higher temperature and longer reaction time ( $48 \mathrm{~h}$ ) were used.

\subsection{Interesterified oils as nutritional sources of long-chain n-3 PUFA}

The dietary reference intake of long-chain n-3 PUFA is based on the current intake by a healthy population, and consists of 135-270 mg a day of EPA+DHA (Institute of Medicine, 2005).

The intake of reduced levels of long-chain n-3 fatty acids has negative consequences on human health, and might occur relatively frequently in situations of irregular fish consumption. The hydroesterification method developed in the present study produced interesterified oils that would provide the adequate levels of intake with a daily intake of one tablespoon equivalent to $8.0 \mathrm{~g}$ (Figure 1) that would

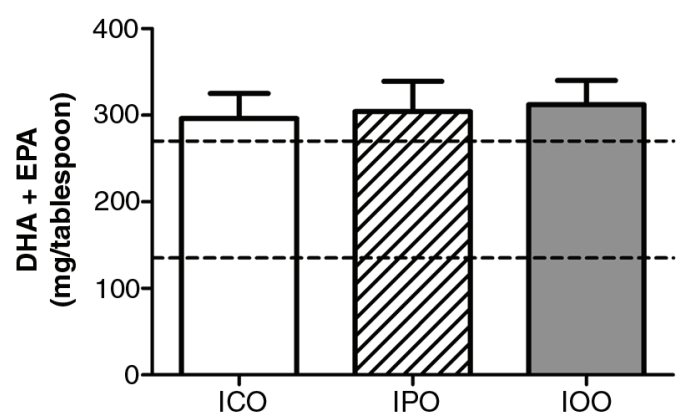

FIGURE 1. Estimated amounts of EPA plus DHA (mg) provided by one tablespoon $(8.0 \mathrm{~g})$ of sample vegetable oils interesterified with fish oil in comparison to the current dietary reference intake (DRI; mg) for these nutrients. I.C.O.: interesterified coconut oil; I.P.O.: interesterified palm oil; I.O.O.: interesterified olive oil. 
contain up to approximately $300 \mathrm{mg}$ of EPA+DHA, depending on the oil in question. When passed in appropriate tests for safety as food, these nutritionally enriched interesterified oils could help increase long-chain n-3 fatty acid consumption, or they could be used as a dietary supplement for specific clinical situations.

Diets that follow the pattern of eating fast food are rich in the omega- 6 family and poor in omega-3 fatty acids, resulting in a ratio of $\omega-6 / \omega-3$ of around 9:1. This ratio can be increased to $17: 1$, when taking into account the western diet in general (Simopoulos, 2001). With the interesterification reaction it was possible to obtain a ratio $n-6 / n-3$ ranging from 1.85 to 2.57 (Table 1 ) in all products. In olive oil this ratio could be reduced from 13 to 2 . Restoring the $n-6 / n-3$ ratio to a better balance will help reduce inflammatory reactions and decrease the risk of chronic disease (Brigelius-Flohé and Traber, 1999). Improving the $n-6 / n-3$ ratio can be achieved by decreasing the intake of omega- 6 fats, increasing the intake of omega-3 fats, or both.

This result is significant in view of the recommendations of the Food and Agriculture Organization of the United Nations (FAO)/World Health Organization (WHO), which recommends an $n-6 / n-3$ ratio of $5: 1$ to $10: 1$.

\section{CONCLUSIONS}

A novel vegetable lipase found in germinated physic nut seeds (Jatropha curcas L.) proved to be efficient in waste fish oil hydrolysis, adding value to this waste by obtaining n-3 polyunsaturated fatty acids (mainly EPA and DHA) and enriching edible vegetable oils with these acids.

The developed interesterification process enabled the production of three nutritionally valued oils rich in EPA and DHA and of high commercial value from waste fish oil and vegetable oils using lipase from Jatropha curcas L. seed (VLP) as a biocatalyst which was never before applied in nutritional foods.

The produced oils can be used to enrich foods with PUFA, especially from the n-3 PUFA family. Our results open up promising new horizons for the use of the biocatalyst presented in the production of both free fatty acids and structured lipids of nutritional interest, since the produced lipids contain a mixture of different fatty acid classes, as a result of the versatility of this biocatalyst, which might be of interest for potential use in varied food products.

\section{ACKNOWLEDGEMENTS}

The financial support received from FAPERJ, CNPq and CAPES (Brazil) is greatfully acknowledged.

\section{REFERENCES}

Akoh CC. 1995. Structured lipids - Enzymatic approach. Inform 6, 1055-1061.

Auerbach MH, Klemann LP, Heydinger JA. 2001. Reducedenergy lipids, in Structured and Modified Lipids, Gunstone, FD, ed, Marcel Dekker, New York, pp. 485-510.

Brigelius-Flohé R, Traber MG. 1999. Vitamin E: Function and metabolism. Fed. Am. Soc. Exp. Biol. J. 13, 1145-1155.

Cavalcanti EDC, Maciel FM, Villeneuve P, Lago, RCA, Machado OLT, Freire DMG. 2007. Acetone power from dormant seeds of Ricinus communis L. Appl. Biochem. Biotechnol. 137, 57-65. http://dx.doi.org/10.1007/s12010-007-9039-1.

Connor WE. 2000. Importance of n-3 fatty acids in health and disease. Am. J. Clin. Nutr. 71, 171-175.

Embrandiri A, Ibrahim MH, Singh RP. 2013. Palm Oil Mill Wastes Utilization; Sustainability in the Malaysian Context. IJSRP 3, 1-7.

Fajardo AR, Akoh CC, Lai OM. 2002. Lipase-catalysed incorporation of n-3 PUFA into palm oil. J. Am. Oil Chem. Soc. 80, 1197-1200. http://dx.doi.org/10.1007/s11746-003-0842-6.

FAO/WHO. 2008. Interim Summary of Conclusions and Dietary Recommendations on Total Fat \& Fatty Acids-From the Joint FAO/WHO Expert Consultation on Fats and Fatty Acids in Human Nutrition, WHO HQ, Geneva, Switzerland.

Foster R, Williamson CS, Lunn J. 2009. Culinary oils and their health effects. Br. Nut. Found. Nut. Bull. 34, 4 47. http:// dx.doi.org/10.1111/j.1467-3010.2008.01738.x.

Frankel, EN. 2011. Nutritional and Biological Properties of Extra Virgin Olive Oil. J. Agric. Food Chem. 59, 785-792. http://dx.doi.org/10.1021/jf103813t.

Freire DMG, Castilho LC. 2008. Enzimas em Biotecnologia: Produção, aplicação e mercado, Ed. Interciência, Rio de Janeiro, pp. 369-385.

Freire DMG, Teles EMF, Bon EPS, Sant'anna GL. 1997. Lipase production by Penicillium restrictum in a bench-scale fermenter effect of carbon and nitrogen nutrition, agitation and aeration. Appl. Biochem. Biotechnol. 64, 409-421. http:// dx.doi.org/10.1007/BF02920442.

Gámez-Meza N, Noriega-Rodríguez JA, Medina-Juárez LA, Ortega-García J, Monroy-Rivera J, Toro-Vázquez FJ, García HS, Angulo-Guerrero O. 2003. Concentration of eicosapentaenoic acid and docosahexaenoic acid from fish oil by hydrolysis and urea complexation. Food Res. Int. 36, 721-727. http://dx.doi.org/10.1016/S0963-9969(03) 00052-8.

Goh SH, Choo YM, Ong SH. 1985. Minor constituents of palm oil. J. Am. Oil Chem. Soc. 62, 237-240. http://dx.doi. org/10.1007/BF02541384.

Gopala KAG, Gaurav R, Ajit SB, Prasanth KPK, Preeti C. 2010. Coconut Oil: Chemistry, Production and Its Applications A Review. Indian Cocon. J. 15-27.

Gunstone FD. 1998. Movements towards tailor-made fats. Prog. Lipid Res. 37 (5), 277-305. http://dx.doi.org/10.1016/ S0163-7827(98)00012-5.

Gunstone FD, Harwood JL, Dijkstra AJ. 2007. The Lipid Handbook - Third Edition CRC Press Taylor \& Francis Group.

Haraldsson GG, Hjaltason B. 2001. Fish oils as sources of important polyunsaturated fatty acids. Structured and Modified Lipids, Gunstone FD, ed.; Dekker: New York, pp. $313-350$.

Hee-Guk B, Tae-Kil E, Won-Kyo J, Se-Kwon K. 2007. Lipase catalyzed production of monoacylglycerols by the esterification of fish oil fatty acid with glycerol. Biotechnol. Bioprocess Eng. 12, 484-490.

Hernández-Martín E, Otero C. 2008. Differente enzyme requirements for the syntehesis of biodiesel: Novozym 435 and Lipozyme TM IM. Bioresource Technol. 99, 277-286. http://dx.doi.org/10.1016/j.biortech.2006.12.024

Institute of Medicine. 2005. Dietary Reference Intakes for Energy and Macronutrients. Washington, DC: National Academy Press. 
Jennings BH, Akoh CC. 2001. Lipase catalyzed modification of fish oil to incorporate capric acid. Food Chem. 72, 273-278. http://dx.doi.org/10.1016/S0308-8146(00)00266-1.

Kasai M, Nosaka N, Maki H, Negishi S, Aoyama T, Nakamura M, Suzuki Y, Tsuji H, Uto H, Okazaki M, Kondo K. 2003. Effect of dietary medium and long-chain triacylglycerols (MLCT) on the accumulation of body fat in healthy humans. Asia Pacific J. Clin. Nutr. 12, 151-160.

Klinkesorn U, H-Kittikun A, Chinachoti P, Sophanodora P. 2004. Chemical transesterification of tuna oil to enriched omega-3 polyunsaturated fatty acids. Food Chem. 87, 415-421. http://dx.doi.org/10.1016/j.foodchem.2003.12.021.

Lee DH, Kim JM, Shin HY, Kang SW, Kim SW. 2006. Biodiesel production using a mixture of immobilized Rhizopus oryzae and Candida rugosa lipases. Biotechnol. Bioprocess Eng. 11, 522-525. http://dx.doi.org/10.1007/BF02932077.

Lee KT, Akoh CC. 1998. Characterization of Enzymatically Synthesized Structured Lipids Containing Eicosapentaenoic, Docosahexaenoic and Caprylic Acids. J. Am. Oil Chem. Soc. 75, 495-499. http://dx.doi.org/10.1007/s11746-998-0253-y.

Lepage G, Roy CC. 1986. Direct transesterification of all classes of lipids in a one-step reaction. J. Lipid Res. 27, 114-120.

Lucas A, Quinlan P, Abrams S, Ryan S, Meah S, Lucas PJ. 1997. Randomized controlled trial of a synthetic triglyceride milk formula for preterm infants, Archives of Disease in Childhood: Fetal \& Neonatal. 77, 128-184.

Macrae AR, Hammond RC. 1985. Present and future applications of lipases. Biotechnol. Genet. Eng. Rev. 3, 193-217. http://dx.doi.org/10.1080/02648725.1985.10647813.

Molendi-Coste O, Legry V, Leclercq, IA. 2011. Why and How Meet n-3 PUFA Dietary Recommendations? Gastroenterol. Res. Prac. ID 364040,11 .

Mu H, Xu X, Høy CE. 1998. Production of specific structured triacylglycerols by lipase-catalyzed interesterification in a laboratory scale continuous reactor. J. Am. Oil Chem. Soc. 75, 1187-1193. http://dx.doi.org/10.1007/s11746-998-0133-5.

Nagao T, Watanabe H, Goto N, Onizawa K, Taguchi H, Matsuo N, Yasukawa T, Tsushima R, Shimasaki H, Itakura H. 2000. Dietary Diacylglycerol Suppresses Accumulation of Body Fat Compared to Triacylglycerol in Men in a DoubleBlind Controlled Trial. J. Nutr. 130, 792-797.

Oh JE, Lee KW, Park HK, Kim JY, Kwon KI, Kim JW, Kim HR, Kim IH. 2009. Lipase Catalyzed Acidolysis of Olive oil with Capric Acid: Effect of Water Activity on incorporation and Acyl Migration. J. Agric. Food Chem. 57 (19), 9280-9283. http://dx.doi.org/10.1021/jf9023245.
Osborn HT, Akoh CC. 2002. Structured lipids - novel fats with medical, nutraceutical, and food applications. Compr. Rev. Food Sci. Food Safety 1, 93-103. http://dx.doi.org/ 10.1111/j.1541-4337.2002.tb00010.x.

Owen RW, Giacosa A, Hull WE, Haubner R, Würtele G, Spiegelhalder B, Bartsch H. 2000. Olive oil consumption and health: the possible role of antioxidants. Lancet Oncol. 1, 107-112. http://dx.doi.org/10.1016/S1470-2045 (00)00015-2.

Rao R, Manohar B, Sambaiah K, Lokesh, BR. 2002. Enzymatic acidolysis in hexane to produce n-3 or n-6 FA-enriched structured lipids from coconut oil: Optimization of reactions by response surface methodology. J. Am. Oil Chem. Soc. 79 (9), 885-890. http://dx.doi.org/10.1007/s11746002-0574-7.

Simopoulos AP 2001 n-3 Fatty acids and human health: Defining strategies for public policy. Lipids 36, 83-89. http://dx.doi.org/10.1007/s11745-001-0687-7.

Sousa JS, Cavalcanti EDC, Aranda DAG, Freire, DMG. 2010. Application of lipase from the physic nut (Jatropha curcas L.) to a new hybrid (enzyme/chemical) hydroesterification process for biodiesel production. J. Mol. Catal. B Enzym. 65, 133-137. http://dx.doi.org/10.1016/j.molcatb. 2010.01.003.

Sreenivasan B. 1978. Interesterification of fats. J. Am. Oil Chem. Soc. 55, 796-805. http://dx.doi.org/10.1007/BF02682651.

Stark AH, Madar Z. 2002. Olive oil as a functional food: epidemiology and nutritional approaches. Nutrition Rev. 60, 170-176. http://dx.doi.org/10.1301/002966402320243250.

Stillwell W. 2006. The role of polyunsaturated lipids in membrane raft function. Scand. J. Food Nutr. 50 (2), 107-113. http:// dx.doi.org/10.1080/17482970601066165.

Wanasundara UN, Shahidi F. 1999. Concentration of omega 3-polyunsaturated fatty acids of seal blubber oil by urea complexation: optimization of reaction conditions. Food Chem. 65, 41-49. http://dx.doi.org/10.1016/S0308-8146 (98)00153-8.

Wu JC, Low WR, Leng Y, Chow Y, Li R, Talukder M, Choi WJ. 2006. Ketoprofen resolution by enzymatic esterification and hydrolysis of the ester product. Biotechnol. Bioprocess Eng. 11, 211-214. http://dx.doi.org/10.1007/BF02932032.

Yankah VV, Akoh CC. 2000. Lipase catalyzed acidolysis of tristearin with oleic or caprylic acids to produce structured lipids. J. Am. Oil Chem. Soc. 77, 495-500. http://dx.doi. org/10.1007/s11746-000-0079-4. 